\title{
Housing the planet: evolution of global housing policies
}

Article

Accepted Version

Creative Commons: Attribution-Noncommercial-No Derivative Works 4.0

Zhang, X. Q. and Ball, M. (2016) Housing the planet: evolution of global housing policies. Habitat International, 54 (3). pp. 161-165. ISSN 0197-3975 doi:

https://doi.org/10.1016/j.habitatint.2015.11.028 Available at https://centaur.reading.ac.uk/60427/

It is advisable to refer to the publisher's version if you intend to cite from the work. See Guidance on citing.

To link to this article DOI: http://dx.doi.org/10.1016/j.habitatint.2015.11.028

Publisher: Elsevier

All outputs in CentAUR are protected by Intellectual Property Rights law, including copyright law. Copyright and IPR is retained by the creators or other copyright holders. Terms and conditions for use of this material are defined in the End User Agreement.

\section{www.reading.ac.uk/centaur}

\section{CentAUR}

Central Archive at the University of Reading

Reading's research outputs online 
Introduction

\section{Housing the Planet:}

\section{Evolution of Global Housing Policies}

Housing touches everyone's heart. It has been the long-term focus in urban development, social and economic policy. Since Habitat I in 1976, some countries have made tremendous progress in meeting the housing needs of their nations, while others still face great challenges of severe housing shortage, substandard housing and slums. Today about one third of the total urban population live in slums. In some developing countries, the majority of urban population lives in poor conditions. For a long period, the housing issues in many countries have only received marginal interest in the academic community and political arena. The political and public concern with the housing conditions, particularly in the developing world, is a relatively recent phenomenon.

The world leaders recognise that the social and economic problems of the developing world are among the great challenges facing human beings. These problems are high on the international and national agenda. Fighting poverty and slums is incorporated in one of the Millennium Development Goals declared by the World Leaders. What accounts for this change in attitude and upsurge of interest in the social and economic issues of the developing countries?

A number of factors can be pinpointed. First, after World War II, there was a wave of national independence movement. The newly independent developing countries had strong desire to change their own fates and to improve their economic and living conditions. Second, there has been increasing recognition by both developing and developed nations about the interdependence and globalisation of the world economy. Third, agencies of United Nations and NGOs actively advocate for social and economic justice and equity among nations and between the rich and the poor. Fourth, the progress and material well-being of people and nations have been at the centre of government policy and academic interests, which have long been searching for the effective mechanism for growth and development. There is an increasing interest in integrating housing into social and economic policies, which advocate inclusiveness and progressiveness. Fifth, the developing countries have trained a large pool of experts and developed a good awareness of the housing issues and their marginalised status in world development.

Globalisation has changed the course of development and exemplifies the mutual interdependence of nations in the world economy. There is also growing awareness of 
interdependence between mankind and nature, and between the rich and the poor. This recognition has shifted the development philosophy and paradigm, and emphasises sustainable development and inclusiveness in opportunities and benefits. Poor people and disadvantaged ones are increasingly regarded as resources rather than burdens. Provision of housing for the poor not only has social benefits but also improves human capital and lifts the economic capacity. Inclusive development promotes cohesive society and binding nations, which increases the mobilisation power and motivates people towards achieving national development goals. Adequate housing for all is now more accepted than ever before. However, different countries separately adopt different housing systems based on their ideological, political, economic, social and cultural theories or beliefs. It was not until 1976 during Habitat I when the housing problem was put on the international agenda. The Vancouver Declaration focused on the role of the governments and the international agencies in formulating their own strategies and on the housing provision. However, these recommendations have had little effect on improving the housing conditions of the poor or on the housing sector as a whole. The strategies did not benefit those who were in most need of housing. They failed to promote integrated approaches to housing through linking land, finance, technology, legistration and urban environment (Duran 1995).

Since Habitat I, the focus of global housing debates has changed, it moves from advocating a strong government role to an enabling role of governments and facilitate the development of housing markets. The representative strategies and policies were illustrated by the United Nations Strategy for Shelter to the Year 2000 in 1988, and World Bank's strategic paper on "Housing: Enabling Markets to Work" in 1992. Habitat II produced a more comprehensive landmark document "The Habitat Agenda" in 1996, which reinforced the previous advocacy on the enabling strategy for the housing sector. The enabling approach emphasised the role of the private sector, communities, and individuals in the housing provision. It regarded housing policies as part of social and economic policies. It proscribed demand side strategies and supply strategies for housing. The demand side strategies focus on the development of property rights, infrastructure improvements, promoting private ownership of land and housing to enable them to be used as collateral for housing finance and investment. However, these strategies did not benefit too much for the poor and for those living in informal settlements. On the other hand, the supply side strategies focus on the provision of infrastructure, introducing realistic affordable and living standards, providing sufficient land for housing development, the development of building industries and technology, and the institutional development for enabling the housing sector to work (Duran, 1995).

Yap Kioe Sheng in his paper on the Enabling Strategies and its Discontent: Low Income Housing Policies and Practices in Asia demonstrated the effectiveness of the enabling strategies in delivering adequate housing to large middle and low middle income sections of the urban population in most economically fast growing Asian countries. The strategy was used as part of a broader agenda of national and global market liberalization which has brought rapid economic 
growth in Asia and an expansion of its urban middle class. Without economic growth, the enabling strategy may not have been as effective.

However, large sections of the urban population still live in inadequate housing. Informal housing has many flaws (e.g. land tenure insecurity, inadequate services, hazardous locations), but also advantages over formal housing, besides lower costs. It is often located near employment centres and offers opportunities for home-based income generation. Informality permits a wide range of tenure forms and housing types to meet the variety of housing needs of the poor. It is flexible and adaptable to different and changing needs, and provides temporary alternative shelter for the poor. Although many cities have policies and programmes to upgrade informal housing, most public housing agencies have been ineffective, as they failed to draw lessons from informal housing development. They supply subsidized housing units which often do not meet the needs of many of the poor and are captured by other income groups. To meet the needs of the poor, the agencies would need to supply affordable housing with a wide range of tenure forms, designs and construction methods that are flexible and adaptable.

Rental housing is one of the much-neglected segments in housing policies. Alan Gilbert in his paper on the International Experience of Rental Housing points out that about 1.2 billion people live in rental housing. Rental housing is an essential ingredient in housing policies and programmes. In fact, in many countries like UK most people (about 70 percent of households) lived in rental housing in 1945. The tenure balance has changed since 1970s when most countries began to introduce policies in favour of home ownership. Gilbert reviewed the evolution of rental housing policies in advanced capitalist countries and former socialist countries. He analyses the challenges and problems facing the development of rental housing. In the policy arena, there is a policy and cultural preference for ownership, and does not provide enough protection over tenants, which hindered the rental housing development. Rent control further discouraged the investment in rental housing. Gilbert notes that rental housing is predominantly the tenure of the poor, with increasing challenges of affordability, more rental housing is a necessity for improving the housing conditions for the poor in most part of the world. Reducing the subsidies to home ownership since most recipients are the better off. Cutting subsidies on mortgage finance and encouraging rental housing development and at least should introduce tenure-neutral policies.

The paper on Housing Provision in 21st Century Europe by Michael Ball looks at the evolution of European housing policies from their strong state-led social welfare tradition. Postwar rapid economic growth made welfare policies feasible. Housing policy was a key element in this state welfare and mixed economic development framework. With very few exceptions, there is an over-riding policy objective that adequate and affordable housing should be available to all. Both home ownership and rental housing were supported through demand-side and supply-side programmes. 
However, the welfare approach to housing often created burdens for not financially strong governments. The resource constraints for public spending and changing socio-economic patterns made some countries more reliance on the enabling approach and market mechanisms to respond to demographic pressures and shocks. The weakening intervention to housing market instability, for example, in the 1980s and 1990s, created particular difficulties for less economically well off home owners in Britain, Sweden, Finland, Spain and some other countries. In some countries, the priority given to curtailing public spending through privatization and shrinkage of public programmes has promoted reductions in capital spending and led to a major shift of housing policy which questioned large subsidies (EU, 1996).

In the $21^{\text {st }}$ Century, European housing markets exhibited considerable instability which worsened affordability for many. The global financial crisis illustrated the difficulty in dealing with housing as an isolated sector, and in detaching it from significant linkages with the financial markets and broad economies. Therefore, economic growth, employment, macroeconomic stability, well-functioning financial markets are crucial for effective functioning of the housing sector. In well-functioning housing systems, governments can and should provide assistance to disadvantaged groups' housing conditions. This can be done through improving the policies, rules and institutional arrangements through different instruments and tools such as tax breaks, subsidies or by controlling prices/rents.

The paper on the Development of Construction and Building Materials Industry in Sudan by Akram Elkhalifa points to an important dimension for housing development. Housing development is often hindered by the backward of construction and building materials industry in developing countries. Elkhalifa identifies the key obstacles for the development of construction and building materials industry in the case of Sudan. The paper examines the capacity and performance of construction and building materials industry from four major categories - i.e. the socio-economic and political environment, the construction industry-specific environment, resources, and institutional framework. Only when the construction and building materials industry's capacity is large and efficient enough, large scale housing provision can be possible.

Facing the large housing shortage, scaling up the housing development is one of the key efforts to help solve the shortage and accommodate about 2 billion additional people who will live in cities over the next 35 years. Robert Buckley et al in their paper on Emergence of Large Scale Housing Programs in many emerging and developing countries examines the rationale, characteristics, idiosyncrasies, management and performances. The paper provides an evaluation framework for assessing large housing programs from four aspects: beneficiary targeting, efficiency, transparency and sustainability. It proposes: (1) to shift emphasis in housing policies 
to better meet the needs of cities as a whole rather than housing suppliers; (2) carefully design regulations to facilitate housing affordability and for better functioning of housing markets ; (3) improving the efficiency and targeting of subsidies. With regard to the role of the government, the paper argues that it should focus on designing a wide range of policy interventions corresponding to income levels, land use, regulatory frameworks and wider urban expansion characteristics and urban policy environment.

The paper on the Housing Provision System in Malaysia by Syafiee Shuid reviewed the evolution of the housing provision system in Malaysia since 1970s, and analysed the roles performed by the different sectors in the housing provision framework in Malaysia. It shows a good supporting case for the enabling role of the government in facilitating the private sector to provide affordable housing for the low and middle income people, while the government maintains an active intervention. The private sector played a predominant role in housing provision in Malaysia despite various controls and regulations imposed by the government. The private sector produced more units for low income housing than the public sector. The government also designs the proportional housing production policy instruments which require the private developers to produce a certain proportion of low income housing for every high or middle income housing project.

Housing affordability is a profound issue for all countries. The paper by Wei Shi et al focuses on the affordable housing policies in China. China's market-oriented housing reform has completely changed the landscape of the housing sector in China. In late 1970s, about 90 percent of urban housing was produced by the government. Now virtually all housing units are produced by the market and bought by households. Home ownership reached 89.3 percent which was much higher than developed countries like USA and Germany. The housing conditions of the urban population have improved remarkably. However, the profit-oriented housing provision created another problem - housing affordability. The proportion of income spent on housing by Chinese households has increased substantially. Housing costs become a burden particularly for low and middle income households and inequality in housing is severe. The paper illustrates the housing affordability in post-reform China and the policy shift since 2006 when housing policy shifts from the emphasis on housing provision through market mechanisms to tackling the housing affordability issue. The development of large scale affordable housing units for low income households through government interventions is a response to the housing affordability issue. The paper raises a fundamental question about the housing policy objectives and priorities. For much of the time since reform, the housing sector is regarded as a growth pole and focuses on the development of real estate markets. Much of the local governments rely on the taxation from the real estate sector. The new housing policy reaffirms that housing is also a social good and a right. The key is how to bring down the cost of housing, the paper suggests several ways to achieve this such as affordable land supply through reducing local governments' fiscal dependence on land revenue and establishing an effective and efficient housing finance system. 
Ivan Turok's paper on housing and the urban premium presents a different perspective on the large scale housing development projects. He points out that there is a risk that mass housing projects may produce inefficient, exclusive and environmentally-damaging urban outcomes. Human settlements policy should serve a broader purpose than constructing more housing units. A carefully-designed approach can help to lift households out of poverty by creating opportunities for people to become more productive. It can help urban areas to function more efficiently, and expand economic activity, investment and jobs. The paper introduces the concept of urban premium which refers to the idea that well-structured cities generate high level economic and social outcomes. It is an attempt to formulate a more synthetic, integrative perspective on urban development, signifying positive value created by the coherent spatial organization of households, firms and public infrastructure. For housing to contribute to the urban premium, it should be situated within a broader city-wide development strategy, with density, connectivity and diversity as core objectives. Implementation is challenging and requires a range of institutional reforms to facilitate coordination and capacity-building.

The paper on the trends, promises and challenges of urbanization in the world by Xing Quan Zhang shows the magnificent scale and rapid pace of urbanization in developing countries, and the different characteristics of urbanization trends in developing and developed countries. It presents the economic powers and opportunities of urbanization. On the other hands, rapid urbanization is triggering huge problems and challenges, such as urban sprawl, urban poverty, higher urban unemployment rates, higher urban costs, housing affordability issues, lack of urban investment, weak urban financial and governance capacities, rising inequality and urban crimes, environmental degradation and etc. It argues that policies and strategies should aim to optimize both the urbanization process and urban functions. Policy responses should link to local conditions, and choose different tools and instruments such as regulatory tools, market-based tools, and spatial tools, for instance, urban density and mixed development.

The past four decades since Habitat I have seen the rapid urbanization and the tremendous progress in the housing sector in developed countries, while many developing countries have encountered a bottleneck of development, stagnation and even worsening of housing conditions. The enabling strategy often works better in economically advanced countries and for the relatively well-off population in the developing countries. The enabling strategy have biased in its approaches towards market mechanisms and in their beneficiaries in favour of well-off population. However, with some exceptions, the enabling strategy is not very effective in addressing the most targeted poor population in most countries.

The market mechanism can be justified in the efficiency of resource allocation, but is difficult to be justified in social terms. Furthermore, the economy and society are increasingly complex. Attempts to identify an ideal model or approach in favour of the market mechanism often run into a particular kind of difficulty. A system is often required to redefine itself and reinvent itself to meet new challenges and accommodate new needs. The interaction and inter-penetration of market mechanisms with other models lead to different types of institutions and new models. 
This special issue intends to identify the most important urban challenges, explore different dimensions or perspectives to make the housing sector and challenges we meet, and leave space for leaders, academics and practicians to infuse their innovation in finding solutions to housing. However, we wish to highlight the following aspects.

\section{The Policy Challenge of Providing More Affordable Housing Where People Want to Live}

It comes as no surprise to readers of this journal that housing shortages remain pressing in many countries and that new policies are needed to improve the situation. The paper by Xing Quan Zhang highlights how rapid urbanisation is triggering further problems; with the world's population increasingly crowding into the relatively small land mass represented by its cities. That housing and urbanisation are so closely linked is unsurprising, of course, if for no other reason than that residential neighbourhoods constitute by far the greatest urban land-use, even in high-density, high-rise cities.

Urban growth is greatest in Asia and Africa but housing affordability problems are global and seem to be worsening for many. These trends call for urgent policy action to be taken but the scale of the action required is daunting. The mobilisation of public and private resources on a truly huge scale is needed and major improvements in the efficiency of policy delivery and management indispensable. Clearly, this cannot be an overnight job with significant enhancement a long-term project. This creates awkward political problems, as politicians who make the difficult choices are unlikely to still be in power to reap the benefits. So, there should preferably be a significant degree of consensus on long-term change and appropriate incentive structures. Volatile economies and fiscal constraints compound the political problems of achieving this.

Moreover, experience in advanced countries as well as elsewhere shows that housing conditions can lag way behind other improvements in living standards, especially for those in the lower half of the income distribution. Evidence also indicates that adverse housing experiences can have considerable knock-on effects on overall life chances and well-being.

The productivity and consumption benefits of urbanisation show a further difficulty of achieving adequate housing provision. It is not only about volumes, standards and costs of housing but also of providing homes where people want them. As Michael Ball notes in his paper, even in a highly urbanised country like England only $6 \%$ of the land mass is covered by housing. That is because people want to live in the country's towns and cities, particularly the most economically dynamic ones, like London. This 'crowding together' spatial framework means that competition for urban land between uses is intense, so policy-wise it is easy to mess up. For example, new housing for low-income groups can be placed miles away from city centres and other sources of 
employment, facing people with impossible choices over homes versus jobs. Ivan Turok takes up this theme in his paper identifying the frequently dis-jointed nature of housing and urban policies, which often seem to be in contrasting, hermetically sealed, policy containers. He notes the severe costs of such an approach in terms of lost economic growth and failed poverty reduction. He calls for better integration of housing with urban policy, elaborating on a number of innovative ideas in this field.

\section{Housing Has Risen up Political Agendas}

So, what housing policies are likely to work best? Experience has shown that in the messy complexity of real world life, simple interventionist programmes are unlikely to achieve their aims; unfortunate side effects and feedback loops in particular derail hopes and swallow up resources. This insight has a long pedigree, although it is often ignored in practice. Arguments in the 1990s made by the World Bank and others about the key importance of enabling private resources to be mobilised through permitting market mechanisms to function were important in placing governments primarily as facilitators rather than initiators and regulators. Yet impatience with progress and concerns over the inequalities occurring alongside change subsequently encouraged housing policy to move up the political agenda in many countries. Simultaneously, a slowing down of regulatory reform has been observable. Regulations and laws, after all, give the impression of doing things. Even if they are not the right ones! Many cities have also found it difficult to accelerate the improvements in infrastructure necessary for better housing conditions and more supply; despite much lower global real rates of interest that make it a propitious time to build. Meanwhile urban management inefficiencies remain commonplace.

\section{Expanding Rented Housing}

One of the most notable accompaniments to this greater housing policy focus has been a widespread revival of state-led housing provision and other large-scale subsidy programmes. It is easy to see why they appeal politically because something manifestly can be seen to have been done, especially when sites are cleared, buildings go up and people move in. But that is obviously a myopic view and broader perspectives on this policy approach are shared themes of several of the papers here - for example, in relation to programmes' fiscal burdens, the opportunity costs, the difficulties of effective targeting and how to exit programmes. Robert Buckley and colleagues chart such projects across a wide number of developing countries and question whether the efficacy of the schemes is always fully thought through. Sayiffee Shuid maps the development of state schemes in Malaysia and identifies some of the distortions as well as the benefits they have created. Wei Shi et al examine the re-revival of state-provided housing in China in the substantial 2011-2015 initiated programme. 
Many, though by no means all, of these state-led schemes relate to subsidised rented housing, whereas much new building in emerging and developing economies has been connected to an expansion of owner occupation amongst middle and higher income groups. Alan Gilbert argues for a much greater policy emphasis towards renting. In a wide-ranging paper, that covers developments over long time periods in advanced countries as well as elsewhere, he argues that too much emphasis has been put on ownership, which is by no means beneficial for all. When they own, those with limited resources are required to lock-up precious resources into a potentially illiquid home, whereas they might be much better-off and more mobile in face of changing economic opportunities if a wider range of rental accommodation existed. The division between formal and informal housing has also blinded some commentators to the significance of renting, because renting is common in informal settlements.

\section{Economies and Finance}

The significance of macroeconomic and financial policies on housing markets is a lesson repeatedly taught. Macroeconomic instability and weak financial systems have stymied housing investment and mortgage markets in much of Africa for decades. The Asian financial crisis of the late 1990s had severe effects on that region's real estate markets and held back urban change for many years. It was followed a decade later by the global financial crisis (GFC), though for a long while that was thought to be primarily a problem associated with developed economies. However, in a globalised world, influences on the later slowdown in emerging economies from 2014 onwards and associated financial tribulations can with hindsight be traced back to it and the policy responses that followed.

Michael Ball highlights the significance of such factors in his piece on Europe. He argues that general economic boom and bust combined with financial excess greatly overshadowed housing policy as a determinant of changes in 21 st century housing provision. Similarly, the trajectory of housing since then has been marked by policies aimed at economic recovery, resolving the Eurozone sovereign debt crisis and avoiding further bouts of financial excess. Amongst several outcomes, they have had the paradoxical effect, for example, of turning previously seemingly stable German housing markets into centres of frenzied price boom. Previous policy parameters have been turned awry. Thus, Europe serves as a warning that housing policy does not operate in a vacuum and that, with regard to housing, other policies may be of greater importance. Nor can those broader policies focus solely on housing related issues. For example, as he illustrates, Sweden's interest rate policies post-GFC indicate how difficult it is to target monetary policy specifically towards an over-heated housing market, because there remains a risk of inadvertently damaging the economy as a whole. 
Of course, as a significant part of any nation's economic and financial system, the flows can work the other way as well: from housing. A traditional Keynesian-style policy-tool is to bolster aggregate demand through fiscal stimuli to housebuilding. Several European countries badly affected by the GFC tried to initiate such policies but those initiatives petered out in face of escalating public debts. As Wei Shi et al note in their paper, China tried such stimulus on a much larger scale with its state-rented housebuilding programme of 2011-2015. This suggests that the push towards renewed state involvement in housing was more pragmatic than ideological and had wider policy aims in mind. Yet, even in China fiscal constraints eventually became binding, with escalating local government debt constraining what can be achieved in terms of further demand stimulus.

\section{How Portable Are Housing Policies?}

One issue over which there is a widespread agreement is that policies have to recognise local circumstances and institutional frameworks. A failure to do so can lead to a policy that was successful somewhere else flopping badly. Of course, there are limits to this maxim, because this does not imply that any policy is justifiable on local circumstances grounds. Moreover, a critical understanding the reasons for any policy success is often preferable to unquestioning cloning.

It is this context that Michael Ball raises the issue of Europe as a 'special case'. It is often pointed to as having exemplary housing policies from which much of the rest of the world can learn. A high level of welfare expenditure in its high-income countries is simultaneously associated with strongly interventionist housing policies, including strong constraints on market activity. The group includes France, Germany, the Netherlands and Sweden. He questions the supposed success of social housing and rent control policies arguing instead that Europe is well housed as much despite those programmes rather than because of them. He suggests that Europe is more interesting for its housing problems than for its model examples.

\section{A Continuing Agenda and a Cautionary Tale}

The urgency of housing problems and the pressing need to be doing something about them offer fertile grounds for grandiose schemes that promise benefits for all once the high entry price has been paid. Such schemes can be observed in abundance in policy debate and practice, and their prominence may even have grown in the 21 st century. The papers here take a more nuanced, gradualist view however. They implicitly or explicitly aim to embed housing within broader theoretical and empirical discourses and wider real dynamics and policies. The hope is that policy makers will think in the same vein. 
Active housing policy now has a long pedigree, with experience amassed across a wide variety of countries and over long-time periods, so that it should be hoped that enough evidence and analysis has been gathered to provide ready and persuasive positive answers. Yet, simple maxims are scarce and there remains a lack of research and comparative analysis on what are after all some of the most complex problems facing humanity over the course of the rest of this century and beyond. Scepticism is important, because one of the most important roles of policy analysis is to hold back sweeping but misguided change.

\section{Guest Editors}

Xing Quan Zhang

Michael Ball

References:

Duran C O (1995), The Impact of Current Global Housing Strategies on the Development of the Housing Sector in Colombia, working paper

EU (1996), Housing Policy in the EU Member States, working document W14 